\title{
Mitral Valve Prolapse: Current Views and Challenges (Review)
}

DOI: $10.17691 / \mathrm{stm} 2017.9 .3 .17$

Received September 6, 2016

(C)

A.V. Klemenoy, MD, DSc, Medical Advisor

City Clinical Hospital No.30, 85a Beryozovskaya St., Nizhny Novgorod, 603157, Russian Federation

Mitral valve prolapse (MVP) is the most common valve abnormality. Many issues relating its diagnosis, epidemiology, prognosis, and genetics have lately been defined more precisely or revised.

The most principal changes in MVP diagnosis are connected with establishing a three-dimensional saddle-like shape of the mitral valve annulus, which made mandatory the assessment of the valve condition from the parasternal longitudinal position during ultrasound examination. Implementation of standard diagnostic criteria based on two-dimensional echocardiography, and making the results of the Framingham Heart Study public made it possible to overcome the contradictions relative to the prevalence of this pathology, which appeared to be lower than it had been considered earlier. Age, gender, and ethnic characteristics of MVP occurrence have been established. Notions not only about the incidence of mitral prolapse development but the severity of its sequelae were subjected to reassessment. If previously MVP was thought to be a disease with serious complications, findings of conducted epidemiological studies gave reasons to consider it as a benign pathology with a low probability of unfavorable consequences. Concurrently, factors of unfavorable prognosis were identified, and mitral regurgitation was recognized to be the main of them.

The results of molecular genetic investigations enriched essentially notion about MVP and improved its diagnosing. At present, this pathology is believed to be a result of multiple genetic disorders caused by identification of several genes linked with the onset of syndromic prolapse, and three loci for nonsyndromic one. Creation of large-scale registers of MVP patients and conduction of genome-wide studies will enable cardiologists to identify new genes related to the emergence of mitral prolapse and provide screening of asymptomatic patients. The leading role in various mechanisms of MVP pathogenesis is played by the impairment of regulation of transforming growth factor beta (TGF- $\beta$ ), understanding of pathogenetic role of which opens new perspectives of conservative treatment of this pathology with the application of antibodies neutralizing TGF- $\beta$, and angiotensin II receptor blockers. Such medical approaches may be rather promising at the early stage of undiagnosed MVP phenotypes, and also serve as an alternative to surgical treatment of clinical complications in patients with a verified diagnosis.

Key words: mitral valve prolapse; mitral prolapse diagnosing; MVP epidemiology; prognosis in prolapses; molecular and genetic basics in MVP; mitral regurgitation; transforming growth factor beta.

Mitral valve prolapse (MVP) is the most common valve abnormality, which occurs in $2-3 \%$ of population [1-5]. This pathology is thought to be the leading cause of isolated mitral insufficiency demanding surgical intervention [3,6-8]. Prolapse is known to be primary and secondary. The secondary (syndromic) MVP is the result of monogenic defects of connective tissue such as Marfan, Loeys-Dietz, Ehlers-Danlos syndromes, osteogenesis imperfecta, pseudoxanthoma elasticum, and recently described aneurysms-osteoarthritis syndrome [8-12]. Typical MVP is characterized by myxomatous degeneration of mitral leaflets and their systolic displacement to the left atrium cavity [13, 14].

In recent years, many notions about diagnosis, epidemiology, prognosis, and genetics of MVP have been made more precise or revised, the most important directions of further investigations have been specified.

\section{Diagnosis of mitral valve prolapse}

Clinical picture of MVP is very heterogeneous; mitral prolapse can be asymptomatic or have clinical

For contacts: Aleksey V. Klemenov, e-mail: klemenov_av@list.ru 
manifestations $[4,6,15,16]$. Physical examination supplemented by two-dimensional echocardiography remains a golden standard of MVP diagnosis [17-19].

A leading mechanism disclosing a diverse MVP semiotics is vegetative dysfunction, though the availability of asymptomatic patients does not permit an unambiguous definition of its pathogenetic role [20, 21]. Nevertheless, the majority of researchers [22-24] consider vegetative changes of homeostasis to be the obligate MVP manifestation. Quite a number of hypotheses have been suggested explaining presence of vegetative dysfunction in MVP, including congenital alterations of perineurium, a systemic defect of biological membranes, perinatal lesion of hypothalamic structures $[20,25,26]$, and a version about a pathogenetic role of hypomagnesemia being lately actively discussed [27].

When two-dimensional echocardiography was first implemented into clinical practice, MVP was diagnosed in $5-15 \%$ and even in $35 \%$ of the examined patients [28, 29]. Such results were mainly connected with erroneous assumption that a mitral valve has a plane configuration. A series of ultrasound examinations [18, 30, 31] allowed the physicians to establish that a mitral valve annulus was saddle-shaped, and made the assessment of the valve condition from the parasternal longitudinal position obligatory [32, 33]. Modern medicine defines MVP as a systolic bulging of one or both mitral valve leaflets by no less than $2 \mathrm{~mm}$ beyond the mitral annulus plane with its obligatory long-axis registration [5].

Three-dimensional echocardiography improved essentially understanding of the mechanics of normal and pathologic mitral valves. This method is of value not only in MVP diagnosis but in determining the tactics of its surgical treatment and outcome assessment [18, 34-38].

\section{Prevalence of mitral valve prolapse}

Notions about the MVP prevalence remained controversial till the announcement of the results of the community-based Framingham Heart Study [1, 39, 40], and transition to the unified criteria of ultrasound diagnosis [30]. In $47(1.3 \%)$ of 3,491 participants of Framingham study according to the findings of twodimensional echocardiography performed in compliance with the standard diagnostic criteria there was detected classic MVP (with thickening of mitral leaflets), in 37 $(1.1 \%)$ nonclassic MVP with an overall prevalence of $2.4 \%$ [1]. Turker et al. [41] report much lower values of mitral prolapse prevalence. Besides, they note a fairly even distribution of the pathology among individuals in each decade from 30 to 80 years of age, and identical occurrence rate among men and women. Their findings differ from older studies [42-45] based on echocardiography in M-mode and/or observations of pedigrees that reported that MVP preferentially afflicted women and older individuals.

MVP is a pathology with genetic predisposition, which however does not occur in newborns [21, 46], and is rarely observed in children (0.3\%) [47] and young people $(0.6 \%)$ [48]. These data convincingly characterize MVP as a progressing disease mainly affecting patients of middle years [1].

MVP prevalence does not depend on ethnicity. Incidence of this pathology in the population sample of American Indians (the Strong Heart Study) [2] and Canadians of South-Asian, European and Chinese origin (the SHARE study) [49] are analogous to the data presented in the Framingham study [1, 39, 40], whose participants were mainly white Americans. Similar results were obtained in the investigations based on Russian population [50].

As far as syndromic MVP in congenital disorders of the connective tissue is concerned, the following trends are noted. In Marfan syndrome, the rate of mitral valve involvement is considerable and makes about $75 \%$, while in more severe variants with myxomatous valve alterations it approximates 28\% [51]; leaflets of aortic and tricuspid valves are also subjected to the characteristic changes [52]. MVP prevalence in patients with Ehlers-Danlos syndrome is much lower (6\%) [9]. A similar trend is noted in Loeys-Dietz syndrome. When 71 patients with mutations of in the TGFBR2 gene (typical for Loeys-Dietz syndrome) and 243 patients with mutations of in the fibrillin gene (FBN1) (typical for Marfan syndrome) were examined, a higher MVP prevalence and mitral regurgitation were found in the last two: 45 and $56 \%$ vs. 21 and $35 \%$, respectively [53]. Abnormalities of the mitral valve appeared also frequent among the patients with aneurysms-osteoarthritis syndrome: MVP was found in $45 \%$ of cases, mitral regurgitation in $27 \%$ [12].

\section{Prognosis in mitral valve prolapse}

Previously, MVP was thought to be a pathology with frequent and serious complications (including stroke, atrial fibrillation, heart failure), and a high demand of surgical correction of mitral insufficiency [3, 6-8, $54,55]$. The results of the Framingham study gave grounds to consider MVP as a benign pathology with a low probability of unfavorable sequelae [1]. In the articles published at the turn of the XXI century with the eloquent titles: "Mysteries of mitral valve prolapse", "Mitral valve prolapse: time for a fresh look", "Mitral valve prolapse: old beliefs yield to new knowledge", "Mitral valve prolapse: the merchant of Venice or much ado about nothing", "When should mitral valve prolapse be considered a real disease?" the authors advocated the idea that serious complications occur in patients with the diagnosis "mitral valve prolapse" as frequent as in the individuals without it [56-60]. In some investigations, in particular, no supporting evidence was found about a close relation of MVP with a cerebral stroke [61, 62], infective endocarditis [63], and other complications [57, 63]. It may be explained by the errors of examination 
methods associated with the comparison of clinically manifestant patients with practically healthy volunteers [1, 54, 55]. Reconsideration of diagnostic criteria for mitral prolapse aggravated the difference in the views on the prevalence of complications in this pathology [30]. In the Framingham study, none of the patients with MVP had a registered heart failure; the rate of atrial fibrillation, cerebral stroke, and syncope appeared to be comparable with the similar sequelae in the individuals without prolapse $(1.2,1.2,3.6 \%$ vs. $1.7,1.5,3.0 \%)$ [1].

Large-scale investigations in Mayo clinic demonstrated clinical heterogenicity of MVP and various prognoses for this pathology [15]. Asymptomatic patients under 50 years of age with a normal left ventricular function have a favorable prognosis even in the presence of heavy mitral regurgitation [15, 64]. Advantages of early surgical correction of the valvular defect compared to a watchful waiting tactics in such patients remain unproved [64-67].

Mitral regurgitation is one of the main risk factors of development of unfavorable cardiovascular events in MVP (congestive heart failure, atrial fibrillation, cerebral disorders, endocarditis) as well as an indication to surgical treatment $[1,54,55,68-70]$. In the Framingham study, asymptomatic MVP in the period from 3 to 16 years showed itself by the signs of regurgitation in a quarter of patients [71]. According to the data from Mayo clinic, the volume of mitral regurgitation increased by more than $8 \mathrm{ml}$ during 1.5 years of follow-up in $51 \%$ of patients with MVP [70]. The two independent factors of the mitral regurgitation volume increase over time were progression of the valve lesion (namely, the appearance of a flail leaflet), and enlargement of a mitral annulus diameter [70]. Atrial fibrillation can also worsen the severity of mitral regurgitation but the intensity of the latter decreases after the restoration of the sinus rhythm [72-74].

In some works $[54,55]$ thickness of the mitral leaflet more than $5 \mathrm{~mm}$ (a sign of myxomatous degeneration) recorded by echocardiography in M-mode was associated with a high risk of endocarditis, mitral regurgitation, and sudden death development. Later and large-scale investigations with the application of twodimensional echocardiography did not confirm this fact [5]. In the course of a long-term follow-up of 833 patients with asymptomatic MVP the predictors of mortality were presence of mitral regurgitation and left ventricular dysfunction at the time of primary examination, whereas age older than 50, enlargement of the left atrial cavity, and presence of mitral regurgitation were the risk factors for cardiovascular disturbances [68].

Availability of a mitral valve flail leaflet is associated with an ambiguous prognosis [75]. Asymptomatic patients with such leaflet and unaltered left ventricular function receiving medicamentous treatment have a low risk of cardiovascular complications [72, 75]. Indications for surgery on the valves in these patients are progression of atrial fibrillation ( $4 \%$ per year) and heart failure $(5.7 \%$ per year). Elderly age, clinical symptoms or decrease of ejection fraction by less than $60 \%$ at the time of establishing the diagnosis are markers of elevated mortality and speak in favor of performing operations on the heart valves $[75,76]$.

The Framingham study has demonstrated equal prevalence of MVP in men and women [1], though a community study in Olmsted County (USA) using current echocardiographic criteria showed that this pathology occurs more often in women and at a younger age than in men [15], with complications being revealed less commonly [76]. Investigation in Mayo clinic detected morphofunctional differences of heart structures in men and women with prolapse. In women, prolapse of the anterior or both mitral leaflets occurs more often, more leaflet thickening, less flail registration rate are noted [77]. Besides, they make an essential portion of patients with moderate and severe mitral regurgitation [5]. As a consequence, in a long-term perspective a higher mortality rate but an equivalent survival time after the operation on the valves are noted in women compared to men [77].

Lately, the focus of researchers' attention has shifted from the valvular mechanism to the state of the left ventricular myocardium in the assessment of prognosis in MVP. Impairment of overall hemodynamics in this pathology was shown to occur not only due mitral incompetence but via the defects of structures and functions of extracellular myocardial matrix, which can cause diastolic dysfunction, contractile capability decrease, and development of secondary cardiomyopathy [78-81].

\section{Molecular biology and genetics of mitral valve prolapse}

Molecular genetic studies have significantly enriched the notion of MVP and allowed cardiologists to improve its diagnosis [8]. By the present time, participation of several genes and factors of their activation in the process of heart valves formation has been proved. Among them are calcineurin stimulating the family of nuclear factors of activated $T$ cells (NFAT), absence of which leads to the fatal valvular defects [82]; Wnt/ $\beta$ catenin, determining the development of endothelial cells [83]; fibroblast growth factor FGF4; homeobox gene Sox4; modulator of transforming growth factor beta (TGF- $\beta$ ); superfamily of signaling proteins SMAD6 [84, 85], the impaired work of which results in abnormal valve thickening. Defects in genes or signaling molecules may induce myxomatous valvular alterations and promote progressing impairment of their mechanical strength during life [86, 87].

A leading role in various mechanisms of pathogenesis of syndromic and non-syndromic MVP is played by the failure of TGF- $\beta$ regulation $[21,88]$. TGF- $\beta$ is a protein controlling a number of physiological processes including angiogenesis, proliferation, cellular differentiation and 
apoptosis of the majority of cells [85, 89, 90]. This representative of cytokines exerts multidirectional action on the extracellular matrix structure. Stimulation of TGF- $\beta$ via a canonic SMAD signaling pathway induces profibrotic effect including deposition of collagen and elastin [91], reduction of proteolytic enzyme expression (matrix metalloproteinases (MMP)) [92], and increase of tissue MMP inhibitor activity [93, 94]. Its stimulation via a non-canonical SMAD-independent signaling pathway results in degradation of the extracellular matrix due to the increased proteolysis via MMP-2, 9 and 13 [95], and elevated activation of MMP with the help of plasminogen activators [96].

Some works $[85,97]$ describe the ability of TGF- $\beta$ to initiate the development of interstitial cells of a valvular leaflet as a pathological phenotype. The importance of TGF- $\beta$ signaling pathway in emergence of sporadic MVP cases has been confirmed [98]. In the experiment on the culture of interstitial cells, induced TGF- $\beta$ production of extracellular matrix is shown to depend on SMAD2/3 and signaling protein $\mathrm{p} 38$ and to decelerate by angiotensin II receptor blockers $[85,98]$. In the study on the surgical mitral valve specimens in patients with prolapse, it is noted that a stimulating effect of TGF- $\beta$ is secondary and occurs in response to inhibiting expression of genes regulating the response to the oxidative stress [99]. Activation of TGF- $\beta$, in its turn, leads to the inhibition of genes responsible for proteoglycan degradation resulting in excessive accumulation of extracellular matrix [5].

Synthesis of extracellular matrix can be induced both in vitro and in vivo by mechanical stretching of the valve, which not only provides its normal development but adaptation to pathological conditions as well [86]. The ability of the valve to restore its previous parameters in response to the weakening of the mechanical action is important in the clinical context: annuloplasty by reducing the load on the valves and chord improves a long-term prognosis for patients with MVP [5].

Pathogenesis of chord rupture and generation of flails are explained by the unique properties of the extracellular matrix [72]. The major part of the valvular complex is known to be avascular just like cartilages and ligaments. A local expression of tendon-specific protein, tenomodulin, antiangiogenic properties of which have been recently discovered, is noted in the valvular chords [100]. In the areas of chord rupture tenomodulin is absent, abnormal vascular formations and intensified expression of vascular endothelial growth factor VEGF-A are observed. On the contrary, in normal unaffected chord areas, an elevated concentration of CD11 $\mathrm{b}^{+}$, $\mathrm{CD}_{14}{ }^{+}$, and vimentin with enhanced expression of MMP-2 and MMP-13 in combination with tenomodulin inhibition is fixed [100].

Syndromic MVP related to hereditary disorders of the connective tissue manifests itself by the same myxomatous changes as primary prolapse. Marfan syndrome is associated with mutations in the FBN1 gene located on 15q15-q21 chromosome [85, 90, 101,
102], it may also be caused by mutation in gene TGF- $\beta$ located on the 3p24.2-p25 chromosome [21, 103]. The role of FBN1 and TGF- $\beta$ mutation in MVP pathogenesis was confirmed by the experiment on mice with the model of Marfan syndrome [104]. In the prolapsed part of the mice valves with FBN1 deficiency, intensification of TGF- $\beta$ expression was noted. Application of antibodies neutralizing TGF- $\beta$ results in the reduction of mitral leaflet thickness and confirms the hypothesis that abnormalities of the mitral valve are linked to the increased level of TGF- $\beta$ [104]. However, a successful correction of many phenotypic manifestations of the Marfan syndrome on the mice models using TGF- $\beta$-neutralizing antibodies is not yet applicable for treating humans [5].

Establishment of interconnection between angiotensin II and TGF- $\beta$ created premises for experimental treatment of mice with mutation in the FBN1 gene with losartan, angiotensin II receptor antagonist [105]. It should be noted that in two experimental groups of mutant mice receiving $\beta$-adrenoblockers and losartan in the doses equivalent by hemodynamic effect, advantage of the latter in the ability to prevent aortic root widening was shown [105]. In the randomized study COMPARE, losartan decreased the rate of aortic root dilatation in comparison with placebo in adults with Marfan syndrome [106]. Nevertheless, the ability to reduce TGF- $\beta$ expression is noted in $\beta$-adrenoblockers as well [102]. In the researches of Lacro et al. [107, 108], where they compared the effect of losartan and atenolol on aorta dilatation and MVP in children and adolescents with Marfan syndrome, no essential difference between the preparations was found.

Loeys-Dietz syndrome is another disease of the connective tissue associated with the pathology of the mitral valve, which is caused by heterozygous mutations in TGFBR1 or TGFBR2 genes encoding subunits of TGF- $\beta$ receptors $[10,85]$. In patients with this pathology, signs of TGF- $\beta$ activity are observed in the form of elevated accumulation of nuclear phosphorylated SMAD2 and concentration increase of connective tissue growth factor, which is induced by TGF- $\beta$ [10, 109]. Aneurism-osteoarthritis syndrome (combination of aortic aneurism, tortuous arteries, facial dysmorphias and early onset of osteoarthritis) caused by mutations in the $S M A D 3$ gene is one more confirmation of the relation of the increased expression of TGF- $\beta$ and myxomatosis of the mitral valve [12].

A high prevalence of mitral prolapse in Marfan syndrome gives grounds to suggest that primary MVP is linked with mutations in the FBN1 gene, but nobody could prove yet this hypothesis. Unsuccessful attempts to find definite genetic defects are connected with absence of systematic study of human genome and phenotypic heterogeneity of the pathology [5].

In 1999, the first genetic locus (MMVP1) for nonsyndromic MVP was mapped on 16p11.2-p12.1 chromosome in the family with the signs of autosomal dominant type of inheritance [110]. In 2003, the second 
locus (MMVP2) on 11p15.4 chromosome was detected [111]. At last, in 2005, the next locus (MMVP3) for autosomal dominant MVP was mapped on 13q31.3-q32 chromosome [112]. Discovery of MMVP3 confirmed genetic heterogeneity of MVP and allowed the scientists to determine the manifestation spectrum, which should be referred to hereditary pathology rather than to the variants of a norm as it has been thought previously [112].

In recent years, the so-called prodromal (for MVP development) morphology, including abnormal anterior cooptation of the leaflets, has attracted attention of investigators [71, 112]. Patients with such abnormality and minimal systolic leaflet displacement have fully or essentially the same "risk haplotype" as those having MVP, similar morphology is observed also in connection with chromosome 11 [112]. Screening of early MVP forms is necessary as rather often this pathology is clinically manifested in the fifth or sixth decade of life in the form of serious heart events [54, 55, 72, 113]. Timely reduction of hemodynamic load on the mitral valve leaflets in genetically predisposed individuals can prevent progression of MVP and appearance of severe mitral regurgitation $[98,104,105]$.

A rare form of myxomatous lesion, X-linked MVP, was first described in 1969 under the name of "myxomatous valvular dystrophy" [114-116]. It is characterized by multiple myxomatous lesions of the valves, though no considerable histopathological differences from heavy forms of autosomal dominant form of MVP are observed.

The case of myxomatous valvular dystrophy combined with hemophilia $A$ in the members of one family [115] allowed researches to collate this variant of MVP with a sex chromosome Xq28; a combination with hemophilia considerably facilitated gene mapping. During the selection of candidate genes, P637Q missense mutation in the filamin $A$ gene was detected in the sick members of the family $[21,115,116]$. The analysis of the mutated filamin gene in other families enabled detection of additional mutations: two new missense mutations (G288R, V711D) and deletion of bpsegment 1944 [116, 117].

Filamins are large cytoplasmic proteins providing crosslinking of actinic filament into three-dimensional structure and serving as transmitters of cellular signals [118-121]. A group of filaments is presented by $A, B$, and $C$ variants, the former being responsible for the development of the heart and vessels [118, 122]. Prenatal death and a vast list of cardiovascular developmental defects including abnormal thickening and deformation of valvular leaflets are typical for hemizygous mice with a null allele of filamin $A[122$, 123]. Defects of other variants of filamin genes ( $B$ and $C$ ) were not accompanied by cardiovascular defects in the experiment on mutant mice [124, 125]. Pathology of the valves may be realized through the impaired signaling function of filamin $A$, which coordinates localization and activity of TGF- $\beta$ receptors-activators of SMAD, especially SMAD2, and can serve as a positive regulator of TGF- $\beta$ signaling $[90,126,127]$. Mutations in the filamin A may explain the similarity of clinical manifestations of Marfan syndrome and non-syndromic MVP, since both these states are characterized by TGF- $\beta$ activity increase. In particular, myxomatosis of mitral valvular leaflets found in mice with FBN1 deficiency reflects excessive activation of TGF- $\beta$ and impairment of filamin A expression regulation [104, 128].

Thus, at present, MVP is assumed to be the result of multiple genetic disorders, which is proved by the identification of several genes related to the occurrence of syndromic mitral prolapse [101, 103], and three loci for non-syndromic prolapse [110-112]. Detection of filamin A mutation in X-linked form of valvular dystrophy [114] confirmed the significance of cytoskeleton not only for structural integrity of the valve but also for the processes in the most important cellular signaling pathways realized, in particular, with participation of TGF- $\beta$. Advances in the technology of DNA sequencing may lead to identification of MMVP1, MMVP2, and MMVP3 genes in the near future. Creation of large-scale registers of patients with MVP and conduction of genome-wide studies will make it possible to identify new genes related to the occurrence of MVP, and to provide screening of asymptomatic patients for whom the development and progression of mitral regurgitation is a real threat $[8,112$, 129]. New perspective ways of MVP management are feasible owing to the results of the operative material investigations in vitro, which demonstrated that typical myxomatous alterations can be prevented with the help of pharmacological agents [98, 102, 130]. Understanding the mechanisms of MVP development will allow the scientists to devise new methods of therapy realized via the effect on various cells and signaling pathways including inhibition of excessive TGF- $\beta$ expression by angiotensin II receptor blockers, manipulations with endothelial cells-precursors, and tissue engineering of heart valves [5, 8, 118]. Such medical approaches are especially perspective at an early stage of undiagnosed MVP phenotypes or as an alternative to surgical treatment of clinical complications in patients with a verified diagnosis.

Study Funding and Conflict of Interests. This study was not supported by any financial sources and the authors have no conflict of interests to disclose.

\section{References}

1. Freed L.A., Levy D., Levine R.A., Larson M.G., Evans J.C., Fuller D.L., Lehman B., Benjamin E.J. Prevalence and clinical outcome of mitral-valve prolapse. $N$ Engl J Med 1999; 341(1): 1-7, http://dx.doi.org/10.1056/ nejm199907013410101.

2. Devereux R.B., Jones E.C., Roman M.J., Howard B.V., Fabsitz R.R., Liu J.E., Palmieri V., Welty T.K., Lee E.T. Prevalence and correlates of mitral valve prolapse in a population-based sample of American Indians: the Strong Heart Study. Am J Med 2001; 111(9): 679-685, https://doi. org/10.1016/s0002-9343(01)00981-0. 
3. Levine R.A., Slaugenhaupt S.A. Molecular genetics of mitral valve prolapse. Curr Opin Cardiol 2007; 22(3): 171-175, https://doi.org/10.1097/hco.0b013e3280f3bfcd.

4. Grau J.B., Pirelli L., Yu P.J., Galloway A.C., Ostrer H. The genetics of mitral valve prolapse. Clin Genet 2007; 72(4): 288-295, https://doi.org/10.1111/j.1399-0004.2007.00865.x.

5. Delling F.N., Vasan R.S. Epidemiology and pathophysiology of mitral valve prolapse: new insights into disease progression, genetics, and molecular basis. Circulation 2014; 129(21): 2158-2170, https://doi.org/10.1161/ circulationaha.113.006702.

6. Hayek E., Gring C.N., Griffin B.P. Mitral valve prolapse. Lancet 2005; 365(9458): 507-518, https://doi.org/10.1016/ s0140-6736(05)70275-0

7. Schoen F.J. Evolving concepts of cardiac valve dynamics: the continuum of development, functional structure, pathobiology, and tissue engineering. Circulation 2008; 118(18): 1864-1880, https://doi.org/10.1161/ circulationaha.108.805911.

8. Levine R.A., Hagége A.A., Judge D.P., Padala M. Dal-Bianco J.P., Aikawa E., Beaudoin J., Bischoff J., BouatiaNaji N., Bruneval P., Butcher J.T., Carpentier A., Chaput M., Chester A.H., Clusel C., Delling F.N., Dietz H.C., Dina C., Durst R., Fernandez-Friera L., Handschumacher M.D., Jensen M.O., Jeunemaitre X.P., Le Marec H., Le Tourneau T., Markwald R.R., Mérot J., Messas E., Milan D.P., Neri T., Norris R.A., Peal D., Perrocheau M., Probst V., Pucéat M., Rosenthal N., Solis J., Schott J.J., Schwammenthal E., Slaugenhaupt S.A., Song J.K., Yacoub M.H.; Leducq Mitral Transatlantic Network. Mitral valve disease - morphology and mechanisms Nat Rev Cardiol 2015; 12(12): 689-710, https:// doi.org/10.1038/nrcardio.2015.161.

9. Dolan A.L., Mishra M.B., Chambers J.B., Grahame R. Clinical and echocardiographic survey of the Ehlers-Danlos syndrome. Br J Rheumatol 1997; 36(4): 459-462, https://doi. org/10.1093/rheumatology/36.4.459.

10. Loeys B.L., Schwarze U., Holm T., Callewaert B.L., Thomas G.H., Pannu H., De Backer J.F., Oswald G.L., Symoens S., Manouvrier S., Roberts A.E., Faravelli F., Greco M.A., Pyeritz R.E., Milewicz D.M., Coucke P.J., Cameron D.E., Braverman A.C., Byers P.H., De Paepe A.M., Dietz H.C. Aneurysm syndromes caused by mutations in the TGF-beta receptor. N Engl J Med 2006; 355(8): 788-798, https://doi.org/10.1056/nejmoa055695.

11. Rubegni P., Mondillo S., De Aloe G., Agricola E., Bardelli A.M., Fimiani M. Mitral valve prolapse in healthy relatives of patients with familial Pseudoxanthoma elasticum. Am J Cardiol 2000; 85(10): 1268-1271, https://doi.org/10.1016/ s0002-9149(00)00745-1.

12. van de Laar I.M., Oldenburg R.A., Pals G., Roos-Hesselink J.W., de Graaf B.M., Verhagen J.M., Hoedemaekers Y.M., Willemsen R., Severijnen L.A., Venselaar H., Vriend G., Pattynama P.M., Collée M., MajoorKrakauer D., Poldermans D., Frohn-Mulder I.M., Micha D., Timmermans J., Hilhorst-Hofstee Y., Bierma-Zeinstra S.M., Willems P.J., Kros J.M., Oei E.H., Oostra B.A., Wessels M.W., Bertoli-Avella A.M. Mutations in SMAD3 cause a syndromic form of aortic aneurysms and dissections with early-onset osteoarthritis. Nat Genet 2011; 43(2): 121-126, https://doi. org/10.1038/ng.744.

13. Rabkin E., Aikawa M., Stone J.R., Fukumoto Y., Libby P., Schoen F.J. Activated interstitial myofibroblasts express catabolic enzymes and mediate matrix remodeling in myxomatous heart valves. Circulation 2001; 104(21): 25252532, https://doi.org/10.1161/hc4601.099489.

14. Guy T.S., Hill A.C. Mitral valve prolapse. Annu Rev Med 2012; 63(1): 277-292, https://doi.org/10.1146/annurevmed-022811-091602

15. Avierinos J.F., Gersh B.J., Melton L.J., Bailey K.R., Shub C., Nishimura R.A., Tajik A.J., Enriquez-Sarano M. Natural history of asymptomatic mitral valve prolapse in the community. Circulation 2002; 106(11): 1355-1361, https://doi. org/10.1161/01.cir.0000028933.34260.09.

16. Bayer-Topilsky T., Suri R.M., Topilsky Y., Marmor Y.N., Trenerry M.R., Antiel R.M., Mahoney D.W., Schaff H.V., Enriquez-Sarano M. Mitral valve prolapse, psychoemotional status, and quality of life: prospective investigation in the current era. Am J Med 2016; 129(10): 1100-1109, https://doi. org/10.1016/j.amjmed.2016.05.004.

17. Bonow R.O., Carabello B.A., Chatterjee K., de Leon A.C. Jr., Faxon D.P., Freed M.D., Gaasch W.H., Lytle B.W., Nishimura R.A., O'Gara P.T., O'Rourke R.A., Otto C.M., Shah P.M., Shanewise J.S. 2008 focused update incorporated into the ACC/AHA 2006 guidelines for the management of patients with valvular heart disease: a report of the American College of Cardiology/American Heart Association Task Force on Practice Guidelines (Writing Committee to Revise the 1998 Guidelines for the Management of Patients With Valvular Heart Disease): endorsed by the Society of Cardiovascular Anesthesiologists, Society for Cardiovascular Angiography and Interventions, and Society of Thoracic Surgeons. Circulation 2008; 118(15): e523-e661, https://doi.org/10.1161/circulationaha.108.190748.

18. Dal-Bianco J.P., Levine R.A. Anatomy of the mitral valve apparatus: role of $2 \mathrm{D}$ and $3 \mathrm{D}$ echocardiography. Cardiol Clin 2013; 31(2): 151-164, https://doi.org/10.1016/j. ccl.2013.03.001.

19. McGhie J.S., de Groot-de Laat L., Ren B., Vletter W., Frowijn R., Oei F., Geleijnse M.L. Transthoracic twodimensional xPlane and three-dimensional echocardiographic analysis of the site of mitral valve prolapse. Int $J$ Cardiovasc Imaging 2015; 31(8): 1553-1560, https://doi.org/10.1007/ s10554-015-0734-7.

20. Loardi C., Alamanni F., Trezzi M., Kassem S., Cavallotti L., Tremoli E., Pacini D., Parolari A. Biology of mitral valve prolapse: the harvest is big, but the workers are few. Int J Cardiol 2011; 151(2): 129-135, https://doi.org/10.1016/j. ijcard.2010.11.004.

21. Padang R., Bagnall R.D., Semsarian C. Genetic basis of familial valvular heart disease. Circ Cardiovasc Genet 2012; 5(5): 569-580, https://doi.org/10.1161/circgenetics.112.962894.

22. Yagoda A.V., Novikova M.V., Gladkikh N.N. Risk factors prognostic significance of cardiac arrhythmias in connective tissue dysplasia. Archive of internal medicine 2015; 1: 60-63.

23. Turker Y., Ozaydin M., Acar G., Ozgul M., Hoscan Y., Varol E., Dogan A., Erdogan D., Yucel H. Predictors of ventricular arrhythmias in patients with mitral valve prolapse. Int J Cardiovasc Imaging 2010; 26(2): 139-145, https://doi. org/10.1007/s10554-009-9514-6.

24. Semyonkin A.A., Tereshchenko Yu.V., Drokina O.V., Zhivilova L.A. Autonomic regulation features in youngs with connective tissue dysplasia. Sibirskiy meditsinskiy zhurnal 2011; 26(3-2): 56-59.

25. Nedostup A.V. Some features of cardiac arrythmia treatment in outpatient practice. Ter Arkh 2006; 78(8): 5-13.

26. Nechaeva G.I. Viktorova I.A., Druk I.V., Vershinina M.V. 
Connective tissue dysplasia: the pulmonary aspects. Pul'monologiya 2004; 2: 116-119.

27. Torshin I.Yu., Gromova O.A., Kalacheva A.G., Oshchepkova E.V., Martynov A.I. Meta-analysis of clinical trials of cardiovascular effects of magnesium orotate. Ter Arkh 2015; 87(6): 88-97.

28. Savage D.D., Garrison R.J., Devereux R.B., Castelli W.P., Anderson S.J., Levy D., McNamara P.M., Stokes J. 3rd, Kannel W.B., Feinleib M. Mitral valve prolapse in the general population. 1. Epidemiologic features: the Framingham Study. Am Heart J 1983; 106(3): 571-576, https:// doi.org/10.1016/0002-8703(83)90704-4.

29. Savage D.D., Devereux R.B., Garrison R.J., Castelli W.P., Anderson S.J., Levy D., Thomas H.E., Kannel W.B., Feinleib M. Mitral valve prolapse in the general population. 2. Clinical features: the Framingham Study. Am Heart J 1983; 106(3): 577-581, https://doi.org/10.1016/00028703(83)90705-6.

30. Levine R.A., Stathogiannis E., Newell J.B., Harrigan P., Weyman A.E. Reconsideration of echocardiographic standards for mitral valve prolapse: lack of association between leaflet displacement isolated to the apical four chamber view and independent echocardiographic evidence of abnormality. J Am Coll Cardiol 1988; 11(5): 1010-1019, https://doi.org/10.1016/ s0735-1097(98)90059-6.

31. Apor A., Nagy A.I., Kovács A., Manouras A., Andrássy P., Merkely B. Three-dimensional dynamic morphology of the mitral valve in different forms of mitral valve prolapse - potential implications for annuloplasty ring selection. Cardiovasc Ultrasound 2016; 14(1): 32, https://doi. org/10.1186/s12947-016-0073-4.

32. Russian Society of Cardiology. Hereditary disorders of connective tissue in cardiology. Diagnosis and treatment. Russian Guidelines (I revision). Rossiyskiy kardiologicheskiy zhurnal 2013; 1(Suppl 1): 1-32.

33. Freed L.A., Benjamin E.J., Levy D., Larson M.G., Evans J.C., Fuller D.L., Lehman B., Levine R.A. Mitral valve prolapse in the general population: the benign nature of echocardiographic features in the Framingham Heart Study J Am Coll Cardiol 2002; 40(7): 1298-1304, https://doi. org/10.1016/s1062-1458(02)01019-x.

34. Maffessanti F., Mirea O., Tamborini G., Pepi M. Threedimensional echocardiography of the mitral valve: lessons learned. Curr Cardiol Rep 2013; 15(7): 377, https://doi. org/10.1007/s11886-013-0377-z.

35. Benenstein R., Saric M. Mitral valve prolapse: role of 3D echocardiography in diagnosis. Curr Opin Cardiol 2012; 27(5): 465-476, https://doi.org/10.1097/hco.0b013e328356afe9.

36. Qamruddin S., Naqvi T.Z. Advances in 3D echocardiography for mitral valve. Expert Rev Cardiovasc Ther 2011; 9(11): 1431-1443, https://doi.org/10.1586/erc.11.137.

37. Lang R.M., Tsang W., Weinert L., Mor-Avi V., Chandra S. Valvular heart disease. The value of 3-dimensional echocardiography. J Am Coll Cardiol 2011; 58(19): 1933-1944, https://doi.org/10.1016/j.jacc.2011.07.035.

38. Jin C.N., Salgo I.S., Schneider R.J., Kam K.K., Chi W.K., So C.Y., Tang Z., Wan S., Wong R., Underwood M., Lee A.P. Using anatomic intelligence to localize mitral valve prolapse on three-dimensional echocardiography. J Am Soc Echocardiogr 2016; 29(10): 938-945, https://doi.org/10.1016/j. echo.2016.07.002.

39. Dawber T.R., Meadors G.F., Moore F.E. Jr. Epidemiological approaches to heart disease: the Framingham
Study. Am J Public Health Nations Health 1951; 41(3): 279 286, https://doi.org/10.2105/ajph.41.3.279.

40. Kannel W.B., Feinleib M., McNamara P.M., Garrison R.J., Castelli W.P. An investigation of coronary heart disease in families. The Framingham offspring study. Am J Epidemiol 1979; 110(3): 281-290.

41. Turker Y., Baltaci D., Basar C., Akkaya M., Ozhan H. The prevalence and clinical characteristics of mitral valve prolapse in a large population-based epidemiologic study: the MELEN study. Eur Rev Med Pharmacol Sci 2015; 19(12): 2208-2212.

42. Strahan N.V., Murphy E.A., Fortuin N.J., Come P.C., Humphries J.O. Inheritance of the mitral valve prolapse syndrome. Discussion of a three-dimensional penetrance model. Am J Med 1983; 74(6): 967-972, https://doi. org/10.1016/0002-9343(83)90792-1.

43. Zua M.S., Dziegielewski S.F. Epidemiology of symptomatic mitral valve prolapse in black patients. $J$ Natl Med Assoc 1995; 87(4): 273-275.

44. Gupta R., Jain B.K., Gupta H.P., Ranawat S.S. Sharma A.K., Gupta K.D. Mitral valve prolapse: two dimensional echocardiography reveals a high prevalence in three to twelve year old children. Indian Pediatr 1992; 29(4): 415-423.

45. Oladapo O.O., Falase A.O. Prevalence of mitral valve prolapse in healthy adult Nigerians as diagnosed by echocardiography. Afr J Med Med Sci 2001; 30(1-2): 13-16.

46. Nascimento R., Freitas A., Teixeira F., Pereira D., Cardoso A., Dinis M., Mendonça I. Is mitral valve prolapse a congenital or acquired disease? Am J Cardiol 1997; 79(2): 226-227, https://doi.org/10.1016/s0002-9149(96)00722-9.

47. Hickey A.J., Wilcken D.E. Age and the clinical profile of idiopathic mitral valve prolapse. Br Heart J 1986; 55(6): 582586, https://doi.org/10.1136/hrt.55.6.582.

48. Flack J.M., Kvasnicka J.H., Gardin J.M., Gidding S.S., Manolio T.A., Jacobs D.R. Jr. Anthropometric and physiologic correlates of mitral valve prolapse in a biethnic cohort of young adults: the CARDIA study. Am Heart J 1999; 138(3 Pt 1): 486492, https://doi.org/10.1016/s0002-8703(99)70151-1.

49. Theal M., Sleik K., Anand S., Yi Q., Yusuf S., Lonn E. Prevalence of mitral valve prolapse in ethnic groups. Can J Cardiol 2004; 20(5): 511-515.

50. Zemtsovskiy E.V., Malev E.G. Mitral valve prolapse: a modern view of the problem. Byulleten' Federal'nogo tsentra serdtsa, krovi $i$ endokrinologii im. V.A. Almazova 2011; 3: 25-30.

51. Taub C.C., Stoler J.M., Perez-Sanz T., Chu J., Isselbacher E.M., Picard M.H., Weyman A.E. Mitral valve prolapse in Marfan syndrome: an old topic revisited. Echocardiography 2009; 26(4): 357-364, https://doi. org/10.1111/j.1540-8175.2008.00825.x.

52. Gu X., He Y., Li Z., Han J., Chen J., Nixon J.V. Echocardiographic versus histologic findings in Marfan syndrome. Tex Heart Inst J 2015; 42(1): 30-34, https://doi. org/10.14503/thij-13-3848.

53. Attias D., Stheneur C., Roy C., Collod-Béroud G., Detaint D., Faivre L., Delrue M.A., Cohen L., Francannet C., Béroud C., Claustres M., Iserin F., Khau Van Kien P., Lacombe D., Le Merrer M., Lyonnet S., Odent S., Plauchu H., Rio M., Rossi A., Sidi D., Steg P.G., Ravaud P., Boileau C., Jondeau G. Comparison of clinical presentations and outcomes between patients with TGFBR2 and FBN1 mutations in Marfan syndrome and related disorders. Circulation 2009; 120(25): 2541-2549, https://doi.org/10.1161/circulationaha.109.887042. 
54. Devereux R.B., Kramer-Fox R., Shear M.K., Kligfield P., Pini R., Savage D.D. Diagnosis and classification of severity of mitral valve prolapse: methodologic, biologic, and prognostic considerations. Am Heart J 1987; 113(5): 1265-1280, https:// doi.org/10.1016/0002-8703(87)90955-0.

55. Zuppiroli A., Rinaldi M., Kramer-Fox R., Favilli S., Roman M.J., Devereux R.B. Natural history of mitral valve prolapse. Am J Cardiol 1995; 75(15): 1028-1032, https://doi. org/10.1016/s0002-9149(99)80718-8.

56. Mulumudi M.S., Vivekananthan K. Mysteries of mitral valve prolapse. Proper treatment requires consideration of all clues. Postgrad Med 2001; 110(2): 43-44, https://doi. org/10.3810/pgm.2001.08.994.

57. Playford D., Weyman A.E. Mitral valve prolapse: time for a fresh look. Rev Cardiovasc Med 2001; 2(2): 73-81.

58. Hayek E., Griffin B. Mitral valve prolapse: old beliefs yield to new knowledge. Cleve Clin J Med 2002; 69(11): 889896, https://doi.org/10.3949/ccjm.69.11.889.

59. Stefanadis C., Toutouzas P. Mitral valve prolapse: the merchant of Venice or much ado about nothing? Eur Heart $J$ 2000; 21(4): 255-258, https://doi.org/10.1053/euhj.1999.1926.

60. Bensaid J. When should mitral valve prolapse be considered a real disease? Ann Cardiol Angeiol 2000; 49(7): 411-413.

61. Gilon D., Buonanno F.S., Joffe M.M., Leavitt M., Marshall J.E., Kistler J.P., Levine R.A. Lack of evidence of an association between mitral-valve prolapse and stroke in young patients. N Engl J Med 1999; 41(1): 8-13, https://doi. org/10.1056/nejm199907013410102.

62. Mas J.L. Cardiopathies associated with a low embolic risk. Rev Neurol 1999; 155(9): 677-683.

63. Koegelenberg C.F., Doubell A., Orth $H$., Reuter $H$. Infective endocarditis in the Western Cape Province of South Africa: a three-year prospective study. QJM 2003; 96(3): 217225, https://doi.org/10.1093/qjmed/hcg028.

64. Rosenhek R., Rader F., Klaar U., Gabriel H., Krejc M., Kalbeck D., Schemper M., Maurer G., Baumgartner H. Outcome of watchful waiting in asymptomatic severe mitral regurgitation. Circulation 2006; 113(18): 2238-2244, https:// doi.org/10.1161/circulationaha.105.599175.

65. Ling L.H., Enriquez-Sarano M., Seward J.B., Orszulak T.A., Schaff H.V., Bailey K.R., Tajik A.J., Frye R.L. Early surgery in patients with mitral regurgitation due to flail leaflets: a long-term outcome study. Circulation 1997; 96(6): 1819-1825, https://doi.org/10.1161/01.cir.96.6.1819.

66. Antiochos P., Muller O., Kirsch M., Agostini M., Qanadli S., Eeckhout E., Vogt P., Prêtre R., Delabays A., Jeanrenaud X., Monney P. Approach to chronic mitral regurgitation in 2016. Rev Med Suisse 2016; 12(520): 10421048.

67. Taramasso M., Gaemperli O., Maisano F. Treatment of degenerative mitral regurgitation in elderly patients. Nat Rev Cardiol 2015; 12(3): 177-183, https://doi.org/10.1038/ nrcardio.2014.210.

68. Avierinos J.F., Detaint D., Messika-Zeitoun D., Mohty D., Enriquez-Sarano M. Risk, determinants, and outcome implications of progression of mitral regurgitation after diagnosis of mitral valve prolapse in a single community. Am J Cardiol 2008; 101(5): 662-667, https://doi.org/10.1016/j. amjcard.2007.10.029.

69. Enriquez-Sarano M., Avierinos J.F., Messika-Zeitoun D., Detaint D., Capps M., Nkomo V., Scott C., Schaff H.V., Tajik A.J. Quantitative determinants of the outcome of asymptomatic mitral regurgitation. N Engl J Med 2005; 352(9): 875-883, https://doi.org/10.1056/nejmoa041451.

70. Enriquez-Sarano M., Basmadjian A.J., Rossi A., Bailey K.R., Seward J.B., Tajik A.J. Progression of mitral regurgitation: a prospective Doppler echocardiographic study. J Am Coll Cardiol 1999; 34(4): 1137-1144, https://doi. org/10.1016/s0735-1097(99)00313-7.

71. Delling F.N., Rong J., Larson M.G., Lehman B., Fuller D., Osypiuk E., Stantchev P., Hackman B., Manning W.J., Benjamin E.J., Levine R.A., Vasan R.S. Evolution of mitral valve prolapse: insights from the Framingham Heart Study. Circulation 2016; 133(17): 1688-1695, https://doi.org/10.1161/ circulationaha.115.020621.

72. Boudoulas K.D., Boudoulas H. Floppy mitral valve (FMV)/mitral valve prolapse (MVP) and the FMV/MVP syndrome: pathophysiologic mechanisms and pathogenesis of symptoms. Cardiology 2013; 126(2): 69-80, https://doi. org/10.1159/000351094.

73. Otani K., Takeuchi M., Kaku K., Haruki N., Yoshitani H., Eto M., Tamura M., Okazaki M., Abe H., Fujino Y., Nishimura Y., Levine R.A., Otsuji Y. Evidence of a vicious cycle in mitral regurgitation with prolapse. Circulation 2012; 126(11 Suppl 1): S214-S221, https://doi.org/10.1161/circulationaha.111.084178.

74. Gertz Z.M., Raina A., Saghy L., Zado E.S., Callans D.J., Marchlinski F.E., Keane M.G., Silvestry F.E. Evidence of atrial functional mitral regurgitation due to atrial fibrillation. $J \mathrm{Am}$ Coll Cardiol 2011; 58(14): 1474-1481, https://doi.org/10.1016/j. jacc.2011.06.032

75. Grigioni F., Tribouilloy C., Avierinos J.F., Barbieri A., Ferlito M., Trojette F., Tafanelli L., Branzi A., Szymanski C., Habib G., Modena M.G., Enriquez-Sarano M. Outcomes in mitral regurgitation due to flail leaflets a multicenter European study. JACC Cardiovasc Imaging 2008; 1(2): 133-141, https:// doi.org/10.1016/j.jcmg.2007.12.005.

76. Ling L.H., Enriquez-Sarano M., Seward J.B., Tajik A.J., Schaff H.V., Bailey K.R., Frye R.L. Clinical outcome of mitral regurgitation due to flail leaflet. $N$ Engl $J$ Med 1996; 335(19): 1417-1423, https://doi.org/10.1056/nejm199611073351902.

77. Avierinos J.F., Inamo J., Grigioni F., Gersh B., Shub C., Enriquez-Sarano M. Sex differences in morphology and outcomes of mitral valve prolapse. Ann Intern Med 2008; 149(11): 787-795, https://doi.org/10.7326/0003-4819-149-11200812020-00003.

78. De Backer J. Cardiovascular characteristics in Marfan syndrome and their relation to the genotype. Verh $\mathrm{K}$ Acad Geneeskd Belg 2009; 71(6): 335-371.

79. Khan R., Sheppard R. Fibrosis in heart disease: understanding the role of transforming growth factorbeta in cardiomyopathy, valvular disease and arrhythmia. Immunology 2006; 118(1): 10-24, https://doi.org/10.1111/j.13652567.2006.02336.x.

80. Malev E.G., Pshepyi A.P., Vasina L.V., Reeva S.V., Timofeev E.V., Korshunova A.L. Left ventricular remodelling and diastolic dysfunction in mitral valve prolapse. Rossiyskiy kardiologicheskiy zhurnal 2013; 100(2): 12-19.

81. Bui A.H., Roujol S., Foppa M., Kissinger K.V., Goddu B., Hauser T.H., Zimetbaum P.J., Ngo L.H., Manning W.J., Nezafat R., Delling F.N. Diffuse myocardial fibrosis in patients with mitral valve prolapse and ventricular arrhythmia. Heart 2017; 103(3): 204-209, https://doi.org/10.1136/heartjnl-2016-309303.

82. de la Pompa J.L., Timmerman L.A., Takimoto H., Yoshida H., Elia A.J., Samper E., Potter J., Wakeham A., Marengere L., Langille B.L., Crabtree G.R., Mak T.W. Role of 
the NF-ATc transcription factor in morphogenesis of cardiac valves and septum. Nature 1998; 392(6672): 182-186, https:// doi.org/10.1038/32419.

83. Hurlstone A.F., Haramis A.P., Wienholds E., Begthel H., Korving J., Van Eeden F., Cuppen E., Zivkovic D., Plasterk R.H., Clevers H. The Wnt/beta-catenin pathway regulates cardiac valve formation. Nature 2003; 425(6958): 633-637, https://doi.org/10.1038/nature02028.

84. Salhiyyah K., Yacoub M.H., Chester A.H. Cellular mechanisms in mitral valve disease. J Cardiovasc Transl Res 2011; 4(6): 702-709, https://doi.org/10.1007/s12265-011-9318-7.

85. Wheeler J.B., Ikonomidis J.S., Jones J.A. Connective tissue disorders and cardiovascular complications: the indomitable role of transforming growth factor-beta signaling. Adv Exp Med Biol 2014; 802: 107-127, https://doi. org/10.1007/978-94-007-7893-1_8.

86. Bischoff J., Aikawa E. Progenitor cells confer plasticity to cardiac valve endothelium. J Cardiovasc Transl Res 2011; 4(6): 710-719, https://doi.org/10.1007/s12265-011-9312-0.

87. Greenhouse D.G., Murphy A., Mignatti P., Zavadil J., Galloway A.C., Balsam L.B. Mitral valve prolapse is associated with altered extracellular matrix gene expression patterns. Gene 2016; 586(1): 56-61, https://doi.org/10.1016/j. gene.2016.04.004.

88. Rizzo S., Basso C., Lazzarini E., Celeghin R., Paolin A., Gerosa G., Valente M., Thiene G., Pilichou K. TGF-beta1 pathway activation and adherens junction molecular pattern in nonsyndromic mitral valve prolapse. Cardiovasc Pathol 2015 24(6): 359-367, https://doi.org/10.1016/j.carpath.2015.07.009.

89. Bertolino P., Deckers M., Lebrin F., ten Dijke P. Transforming growth factor-beta signal transduction in angiogenesis and vascular disorders. Chest 2005; 128(6 Suppl): 585S-590S, https://doi.org/10.1378/chest.128.6_suppl.585s.

90. LaHaye S., Lincoln J., Garg V. Genetics of valvular heart disease. Curr Cardiol Rep 2014; 16(6): 487, https://doi. org/10.1007/s11886-014-0487-2.

91. Ignotz R.A., Massague J. Transforming growth factorbeta stimulates the expression of fibronectin and collagen and their incorporation into the extracellular matrix. $\mathrm{J}$ Biol Chem 1986; 261(9): 4337-4345.

92. Yan C., Boyd D.D. Regulation of matrix metalloproteinase gene expression. J Cell Physiol 2007; 211(1): 19-26, https://doi.org/10.1002/jcp.20948.

93. Kwak H.J., Park M.J., Cho H., Park C.M., Moon S.I., Lee H.C., Park I.C., Kim M.S., Rhee C.H., Hong S.I. Transforming growth factor-beta1 induces tissue inhibitor of metalloproteinase-1 expression via activation of extracellular signal-regulated kinase and Sp1 in human fibrosarcoma cells. Mol Cancer Res 2006; 4(3): 209-220, https://doi. org/10.1158/1541-7786. mcr-05-0140.

94. Jones J.A., Spinale F.G., Ikonomidis J.S. Transforming growth factor-beta signaling in thoracic aortic aneurysm development: a paradox in pathogenesis. J Vasc Res 2009; 46(2): 119-137, https://doi.org/10.1159/000151766.

95. Kim E.S., Kim M.S., Moon A. TGF-beta-induced upregulation of MMP-2 and MMP-9 depends on p38 MAPK, but not ERK signaling in MCF10A human breast epithelial cells. Int J Oncol 2004; 25(5): 1375-1382, https://doi.org/10.3892/ ijo.25.5.1375.

96. Laiho M., Saksela O., Keski-Oja J. Transforming growth factor beta alters plasminogen activator activity in human skin fibroblasts. Exp Cell Res 1986; 164(2): 399-407, https://doi. org/10.1016/0014-4827(86)90038-8.
97. Disatian S., Ehrhart E.J. 3rd, Zimmerman S., Orton E.C. Interstitial cells from dogs with naturally occurring myxomatous mitral valve disease undergo phenotype transformation. $J$ Heart Valve Dis 2008; 17(4): 402-411.

98. Geirsson A., Singh M., Ali R., Abbas H., Li W., Sanchez J.A., Hashim S., Tellides G. Modulation of transforming growth factor-beta signaling and extracellular matrix production in myxomatous mitral valves by angiotensin II receptor blockers. Circulation 2012; 126(11 Suppl 1): 189 197, https://doi.org/10.1161/circulationaha.111.082610.

99. Hulin A., Deroanne C., Lambert C., Defraigne J.O., Nusgens B., Radermecker M., Colige A. Emerging pathogenic mechanisms in human myxomatous mitral valve: lessons from past and novel data. Cardiovasc Pathol 2013; 22(4): 245-250, https://doi.org/10.1016/j.carpath.2012.11.001

100. Kimura N., Shukunami C., Hakuno D., Yoshioka M., Miura S., Docheva D., Kimura T., Okada Y., Matsumura G., Shin'oka T., Yozu R., Kobayashi J., Ishibashi-Ueda H., Hiraki Y., Fukuda K. Local tenomodulin absence, angiogenesis, and matrix metalloproteinase activation are associated with the rupture of the chordae tendineae cordis. Circulation 2008; 118(17): 17371747, https://doi.org/10.1161/circulationaha.108.780031.

101. Dietz H.C., Cutting G.R., Pyeritz R.E., Maslen C.L., Sakai L.Y., Corson G.M., Puffenberger E.G., Hamosh A., Nanthakumar E.J., Curristin S.M., Stetten G., Meyers D.A., Francomano C.A. Marfan syndrome caused by a recurrent de novo missense mutation in the fibrillin gene. Nature 1991; 352(6333): 337-339, https://doi.org/10.1038/352337a0.

102. Kumar A., Agarwal S. Marfan syndrome: an eyesight of syndrome. Meta Gene 2014; 2: 96-105, https://doi. org/10.1016/j.mgene.2013.10.008.

103. Mizuguchi T., Collod-Beroud G., Akiyama T., Abifadel M., Harada N., Morisaki T., Allard D., Varret M., Claustres M., Morisaki H., Ihara M., Kinoshita A., Yoshiura K., Junien C., Kajii T., Jondeau G., Ohta T., Kishino T., Furukawa Y., Nakamura Y., Niikawa N., Boileau C., Matsumoto $\mathrm{N}$. Heterozygous TGFBR2 mutations in Marfan syndrome. Nat Genet 2004; 36(8): 855-860, https://doi. org/10.1038/ng1392.

104. Ng C.M., Cheng A., Myers L.A., MartinezMurillo F., Jie C., Bedja D., Gabrielson K.L., Hausladen J.M., Mecham R.P., Judge D.P., Dietz H.C. TGF-beta-dependent pathogenesis of mitral valve prolapse in a mouse model of Marfan syndrome. J Clin Invest 2004; 114(11): 1586-1592, https://doi.org/10.1172/jci22715.

105. Habashi J.P., Doyle J.J., Holm T.M., Aziz H., Schoenhoff F., Bedja D., Chen Y., Modiri A.N., Judge D.P., Dietz H.C. Angiotensin II type 2 receptor signaling attenuates aortic aneurysm in mice through ERK antagonism. Science 2011; 332(6027): 361-365, https://doi.org/10.1126/ science.1192152.

106. Groenink M., den Hartog A.W., Franken R., Radonic T., de Waard V., Timmermans J., Scholte A.J., van den Berg M.P., Spijkerboer A.M., Marquering H.A., Zwinderman A.H., Mulder B.J. Losartan reduces aortic dilatation rate in adults with Marfan syndrome: a randomized controlled trial. Eur Heart J 2013; 34(45): 3491-500, https:// doi.org/10.1093/eurheartj/eht334.

107. Lacro R.V., Guey L.T., Dietz H.C., Pearson G.D., Yetman A.T., Gelb B.D., Loeys B.L., Benson D.W., Bradley T.J., De Backer J., Forbus G.A., Klein G.L., Lai W.W., Levine J.C., Lewin M.B., Markham L.W., Paridon S.M., Pierpont M.E., Radojewski E., Selamet Tierney E.S., 
Sharkey A.M., Wechsler S.B., Mahony L.; Pediatric Heart Network Investigators. Characteristics of children and young adults with Marfan syndrome and aortic root dilation in a randomized trial comparing atenolol and losartan therapy. Am Heart J 2013; 165(5): 828-835.e3, https://doi.org/10.1016/j. ahj.2013.02.019.

108. Lacro R.V., Dietz H.C., Sleeper L.A., Yetman A.T., Bradley T.J., Colan S.D., Pearson G.D., Selamet Tierney E.S., Levine J.C., Atz A.M., Benson D.W., Braverman A.C., Chen S., De Backer J., Gelb B.D., Grossfeld P.D., Klein G.L., Lai W.W., Liou A., Loeys B.L. Atenolol versus losartan in children and young adults with Marfan's syndrome. N Engl J Med 2014; 371(22): 2061-2071, https://doi.org/10.1056/nejmoa1404731.

109. Judge D.P., Rouf R., Habashi J., Dietz H.C. Mitral valve disease in Marfan syndrome and related disorders. J Cardiovasc Transl Res 2011; 4(6): 741-747, https://doi. org/10.1007/s12265-011-9314-y.

110. Disse S., Abergel E., Berrebi A., Houot A.M., Le Heuzey J.Y., Diebold B., Guize L., Carpentier A., Corvol P., Jeunemaitre $X$. Mapping of a first locus for autosomal dominant myxomatous mitral-valve prolapse to chromosome 16p11.2-p12.1. Am J Hum Genet 1999; 65(5): 1242-1251, https://doi.org/10.1086/302624.

111. Freed L.A., Acierno J.S., Dai D., Leyne M., Marshall J.E., Nesta F., Levine R.A., Slaugenhaupt S.A. A locus for autosomal dominant mitral valve prolapse on chromosome 11p15.4. Am J Hum Genet 2003; 72(6): 1551-1559, https://doi. org/10.1086/375452.

112. Nesta F., Leyne M., Yosefy C., Simpson C., Dai D., Marshall J.E., Hung J., Slaugenhaupt S.A., Levine R.A. New locus for autosomal dominant mitral valve prolapse on chromosome 13: clinical insights from genetic studies. Circulation 2005; 112(13): 2022-2030, https://doi.org/10.1161/ circulationaha.104.516930.

113. Klemenov A.V. Idiopathic mitral valve prolapse in adulthood and old age. Klinicheskaya gerontologiya 2001; 7(56): $57-59$.

114. Tourneau T., Lardeux A., Kyndt F., Mérot J., Hagege A., Levine R., Marec H., Schott J.-J., Probst V. New findings in mitral valve prolapse related to filamin-A mutations. Archives of Cardiovascular Diseases Supplements 2012; 4(1): 59, https://doi.org/10.1016/s1878-6480(12)70583-9.

115. Kyndt F., Schott J.J., Trochu J.N., Baranger F., Herbert O., Scott V., Fressinaud E., David A., Moisan J.P., Bouhour J.B., Le Marec H., Benichou B. Mapping of X-linked myxomatous valvular dystrophy to chromosome Xq28. Am J Hum Genet 1998; 62(3): 627-632, https://doi. org/10.1086/301747.

116. Lardeux A., Kyndt F., Lecointe S., Marec H., Mérot J., Schott J.J., Tourneau T., Probst V. Filamin-Arelated myxomatous mitral valve dystrophy: genetic, echocardiographic and functional aspects. J Cardiovasc Transl Res 2011; 4(6): 748-756, https://doi.org/10.1007/s12265-0119308-9.

117. Duval D., Labbé P., Bureau L., Le Tourneau T., Norris R.A., Markwald R.R., Levine R., Schott J.J., Mérot J. MVP-associated filamin A mutations affect FInA-PTPN12(PTPPEST) interactions. J Cardiovasc Dev Dis 2015; 2(3): 233247, https://doi.org/10.3390/jcdd2030233.

118. Nakamura F., Stossel T.P., Hartwig J.H. The filamins: organizers of cell structure and function. Cell Adh Migr 2011; 5(2): 160-169, https://doi.org/10.4161/cam.5.2.14401.

119. Ciobanasu C., Faivre B., Le Clainche C. Integrating actin dynamics, mechanotransduction and integrin activation: the multiple functions of actin binding proteins in focal adhesions. Eur J Cell Biol 2013; 92(10-11): 339-348, https:// doi.org/10.1016/j.ejcb.2013.10.009.

120. Razinia Z., Mäkelä T., Ylänne J., Calderwood D.A. Filamins in mechanosensing and signaling. Annu Rev Biophys 2012; 41: 227-246, https://doi.org/10.1146/annurevbiophys-050511-102252.

121. Jahed Z., Shams H., Mehrbod M., Mofrad M.R. Mechanotransduction pathways linking the extracellular matrix to the nucleus. Int Rev Cell Mol Biol 2014; 310: 171-220, https://doi.org/10.1016/b978-0-12-800180-6.00005-0.

122. Norris R.A., Moreno-Rodriguez R., Wessels A., Merot J., Bruneval P., Chester A.H., Yacoub M.H., Hagège A., Slaugenhaupt S.A., Aikawa E., Schott J.J., Lardeux A., Harris B.S., Williams L.K., Richards A., Levine R.A., Markwald R.R. Expression of the familial cardiac valvular dystrophy gene, filamin-A, during heart morphogenesis. Dev Dyn 2010; 239(7): 2118-2127, https://doi.org/10.1002/ dvdy.22346.

123. Sauls K., Toomer K., Williams K., Johnson A.J., Markwald R.R., Hajdu Z., Norris R.A. Increased infiltration of extra-cardiac cells in myxomatous valve disease. $J$ Cardiovasc Dev Dis 2015; 2(3): 200-213, https://doi.org/10.3390/ jcdd2030200.

124. Dalkilic I., Schienda J., Thompson T.G., Kunkel L.M. Loss of filamin $C$ (FLNc) results in severe defects in myogenesis and myotube structure. Mol Cell Biol 2006; 26(17): 6522-6534, https://doi.org/10.1128/mcb.00243-06.

125. Zhou X., Tian F., Sandzén J., Cao R., Flaberg E., Szekely L., Cao Y., Ohlsson C., Bergo M.O., Borén J., Akyürek L.M. Filamin B deficiency in mice results in skeletal malformations and impaired microvascular development. Proc Natl Acad Sci USA 2007; 104(10): 3919-3924, https://doi. org/10.1073/pnas.0608360104.

126. Sasaki A., Masuda Y., Ohta Y., Ikeda K., Watanabe K. Filamin associates with Smads and regulates transforming growth factor-beta signaling. J Biol Chem 2001; 276(21): 17871-17877, https://doi.org/10.1074/jbc. $\mathrm{m} 008422200$.

127. Cushing M.C., Liao J.T., Anseth K.S. Activation of valvular interstitial cells is mediated by transforming growth factor-beta1 interactions with matrix molecules. Matrix Biol 2005; 24(6): 428-437, https://doi.org/10.1016/j. matbio.2005.06.007.

128. Charitakis K., Basson C.T. Degenerating heart valves: fill them up with filamin? Circulation 2006, 115(1):2-4, https://doi.org/10.1161/circulationaha, 106.663237.

129. Dina C., Bouatia-Naji N ., Tucker N., Delling FN., Toomer K., Durst R., Perrocheau M., Fernandez-Friera L., Solis J., Le Tourneau T., Chen M.H., Probst Y., Bosse Y., Pibarot P., Zelenika D., Lathrop M., Hercberg S., Roussel R., Benjamin E.J., Bonnet F., Lo S.H., Dolmatova E., Simonet F., Lecointe S., Kyndt F., Redon R., Le Marec H., Eroguel P., Ellinor P.T., Vasan R.S., Bruneval P., Markwald R.R., Norris R.A., Milan D.J., Slaugenhaupt S.A., Levine R.A., Schott J.J., Hagege A.A., Jeunemaitre X. Genetic association analyses highlight biological pathways underlying mitral valve prolapse. Nat Genet 2015; 47(10): 1206-1211, https://doi. org/10.1038/ng.3383.

130. Siordia J.A. Current discoveries and interventions for barlow's disease Curr Cardiol Rep 2016; 18(8): 73, https://doi. org/10.1007/s11886-016-0754-5. 